\title{
FinTech in COVID-19 and Beyond: What Factors Are Affecting Customers' Choice of FinTech Applications?
}

\author{
Mohammad K. Al nawayseh \\ MIS Department, Business School, the University of Jordan, Amman 11942, Jordan; m.nawaiseh@ju.edu.jo
}

Received: 24 August 2020; Accepted: 11 November 2020; Published: 17 November 2020

\begin{abstract}
Accessing financial services is considered one of the main challenges facing communities during crises. This research studies the role of using FinTech applications to build resilience during the COVID-19 pandemic. The research empirically examines the factors affecting Jordanian citizens' intention to use FinTech applications. The sample of the research comprised 500 potential FinTech service users in Jordan. Based on the research conceptual model, five hypotheses were developed and tested using structural equation modeling techniques (SEM-PLS). The research results indicate that perceived benefits and social norms significantly affect the intention to use FinTech applications. However, it has been found that perceived technology risks do not significantly affect the intention to use FinTech applications. Moreover, the results also indicate that customer trust is significantly mediating the relationship between perceived risks and intention to use FinTech applications. FinTech service providers should insure that their products are easy to use, fulfill needs and protect consumers' data in order to ensure trust, hence positively influencing consumer adoption.
\end{abstract}

Keywords: FinTech; open innovation; resilience; Jordan; COVID-19

\section{Introduction}

In modern economies, the financial service industry performs a range of functions to facilitate financial economic activities. Accessing financial services is considered one of the main enablers to build socioeconomic resilience during crises [1,2]. Advancements in information and communication technologies (ICT) over recent decades have revolutionized the financial industry, enabling more efficient and innovative service delivery. Digital finance innovations help vulnerable communities, particularly in developing countries, to access financial resources [3-5]. Financial technology (FinTech) offers the financial industry, and consumers, advancements that make their transactions less expensive, more convenient and more secure [3,6]. Financial institutions and technology firms are increasingly investing in FinTech technologies, which attracted global investments of $\$ 40$ billion in 2019 [7].

However, the FinTech maturation process is still challenging, and more time and efforts for long-term success and public acceptance are necessary, particularly for retail financial services $[5,8]$. This challenge of balancing between potential benefits and risks in FinTech innovations is more acute in the developing world [5]. People with less socioeconomic resources are not well informed about financial products, and are not likely to seek financial information [4,9]. Notably, mobile services play an important role in providing financial service to unbanked populations in developing countries $[2,4,10]$. However, few empirical studies have been conducted to explore adoption and diffusion aspects of FinTech, especially in developing countries [2,4,11].

The world is currently facing the COVID-19 pandemic, with its major global, medium- and long-term impacts on health services and economy, and Jordan is no exception [12,13]. In Jordan as everywhere in the world, the government applied preventive measures, such as strict lockdown and social distancing, to protect people's lives [14,15]. These measures had many consequences on the economy and households, as most public and private services were closed, and are being 
tentatively reopened in stages. According to recent reports from the International Monetary Fund (IMF) and the World Bank, the Jordanian economy is projected to contract around $4 \%$ as a result of this crisis $[16,17]$. This negative impact comes through various channels, particularly trade, tourism and service sectors [16,17]. Moreover, recent UNDP (United Nations Development Programme) surveys [18] indicated that although Jordan has curbed the spread of COVID-19, the impact of this crisis on households was significant. Most households reported that they have faced many difficulties during the lockdown, such as food access and livelihood loss, resulting in difficulties to access financial services.

In response to these difficulties, Jordan has started early to implement procedures to help its economy during the crisis, including supporting citizens to use FinTech applications in order to accomplish their financial transactions during the lockdown and even after $[11,15]$. The government of Jordan announced that mobile digital wallets should be used as the main method to transfer salaries for the private sector and the unbanked population, who depend heavily on cash [11]. However, FinTech applications' success in Jordan face numerous economic challenges, and issues associated with the high influx of refugees, low mobile wallet penetration rates, cultural barriers, low financial and digital literacy, and the most important is low user trust [19].

This research studies the role of using FinTech applications in building economic resilience by empirically examining the factors that affect Jordanian citizens' intention to use FinTech applications.

The remainder of this research is organized as follows. Section 2 presents the previous literature and the theoretical background, Section 3 discusses the research model and the research hypotheses. Section 4 describes the research methodology, followed by the results and the statistical analysis in Section 5. Section 6 discusses the findings, and Section 7 presents the conclusion, research implications, and limitations, and suggesting future research directions.

\section{Background and Theoretical Foundation}

\subsection{FinTech and Open Innovation}

FinTech or financial technology is an emerging field that can be described as innovative financial products and services enabled by ICT $[3,7,20]$. Recently, FinTech applications have expanded to include even innovations in financial literacy and education $[3,6,21]$. Although the role of ICT in financial institutions is not new, FinTech offers new forms of value creation models through restructuring and coordinating the flow of financial information [3,22]. The role of ICT in FinTech is not only as enabler or facilitator, rather it is revolutionizing the entire traditional financial system $[3,7,23]$. FinTech firms are altering traditional online financial models through mechanisms of disintermediation, extension of access, hybridization, financialization and personalization $[3,6,7,24]$. The financial service industry has been enabled to provide entirely new, innovative financial solutions due to the changing role of ICT. Changing consumer behavior, changing ecosystems and supportive regulations all enable the financial service industry to provide entirely new, innovative financial solutions $[3,7,22]$. These solutions can be distinguished into five main categories: products and services, structures, processes, systems and business models [3,7]. FinTech includes a variety of mobile services, making payments, transferring money, making loan requests, purchasing insurance, managing assets, making investments and crowdfunding [3,4,6,22]. The development of FinTech applications in the financial services industry over recent decades passed through mainly three phases: internal, provider and customer-oriented digitization [3,7]. New technology developments such as smart devices, cloud computing, AI and machine learning, big data, and recently blockchain, have changed the role of ICT in the FinTech industry in terms of new opportunities, risks and legal concerns $[3,6,7,21]$. In relation to theses technological developments, the main areas of FinTech applications are finance and investment, payments and infrastructure, operations and risk management, data security and monetization, and customer interface [3,6].

The FinTech landscape is an emerging association between industry participants; business incumbents, FinTech startups and customers $[3,25]$. This landscape is characterized in terms of competition and 
cooperation with other industry participants and by related strategies for value creation $[3,7,26,27]$. This win-win partnership between financial industry participants has never been accomplished without open innovation initiatives [24-26]. The open innovation approach is used to enhance organizational capacity for innovations $[24,25]$. This approach allows companies to efficiently utilize their business environment stakeholders to become more agile to such changes by reducing development cycles and streamlining processes $[25,26]$.

In Jordan, supportive regulations and policies, reliable telecommunications infrastructure and products, as well as many digital finance inclusion initiatives, all encourage the use of FinTech applications. The main Jordanian stakeholders in FinTech are the Jordanian Central Bank (JCB) as a regulator, Jo-PACC, commercial banks, MEPS, eFAWATEERcom and ZainCash with more than half a million subscribers. According to recent JCB statistics, FinTech firms provided mobile wallets and payment platforms that facilitated transactions worth more than $\$ 170$ million in 2019 [11].

\subsection{Role of FinTech in Resilience}

Theoretical literature on resilience has grown in recent years, covering multiple domains such as health, disaster response and many more [1,27]. Resilience can be viewed as the ability of individuals to cope with external shocks in their environment $[1,4,27,28]$. Individuals can positively adapt, using resources and traits like problem-solving skills during challenging circumstances $[1,28]$. Information and communications technologies (ICT) play a major role in building resilient communities and individuals during crises or emergencies [27,29-31]. Digital finance innovations help vulnerable communities, especially in developing countries, to access financial resources, increasing their economic resilience during crises [1,2,32-36]. Mobile applications provide individuals in developing countries with a range of financial services such as payments, savings, loans and microcredit $[1,2,4,7,28,37]$. Mobile services like M-Pesa and GCASH are leading examples of digital finance innovations providing financial services for users in the developing countries $[10,30,34,37,38]$. According to recent studies, FinTech will provide $62.5 \%$ of unbanked Jordanians with financial products and services [19].

\subsection{Prior Research on FinTech Adoption}

Despite the fact that many financial innovations are heavily covered in previous literature, many new innovations are still not well studied. Most recent studies have focused on innovations like mobile banking and mobile payments while few have been found on innovations like mobile wallets, mobile money and blockchain [39-42].

FinTech applications adoption is mainly influenced by contextual factors such as social influence, risk and trust [8,35,43-45]. However, most of the previous literature on FinTech adoption has focused on the technological factors while not considering the social antecedents [35,46-49]. For instance, technology adoption theories like the technology acceptance model (TAM) were used heavily in mobile services research $[35,40,45,46,50-52]$, while the use of behavioral theories like the unified theory of acceptance and use of technology (UTAUT) and the extended valence framework is still limited $[35,53]$.

The original UTAUT model holds four main constructs (performance expectancy, effort expectancy, social influence, and facilitating conditions) as determinants of usage intention and behavior. The variables of gender, age, experience and voluntariness are used as moderators to moderate the impact of the four main constructs on usage intention and behavior [54]. Moreover, the extended valence framework indicates that consumers' intention to use the technology is affected by their perceptions of benefits, risk and trust [55]. Accordingly, the UTAUT model combined with the extended valence framework is considered more appropriate for FinTech adoption to give more insights on additional contextual factors such as risk and trust [55,56].

\section{Research Model}

This study used a modified model of UTAUT by incorporating additional contextual factors from the extended valence framework, such as trust and risk. As such, combining these two theories gives 
more understanding of FinTech adoption; the UTAUT covers perceived benefits, social influence and behavioral intention combined with trust and risk from the extended valence framework. The proposed model is summarized in Figure 1.

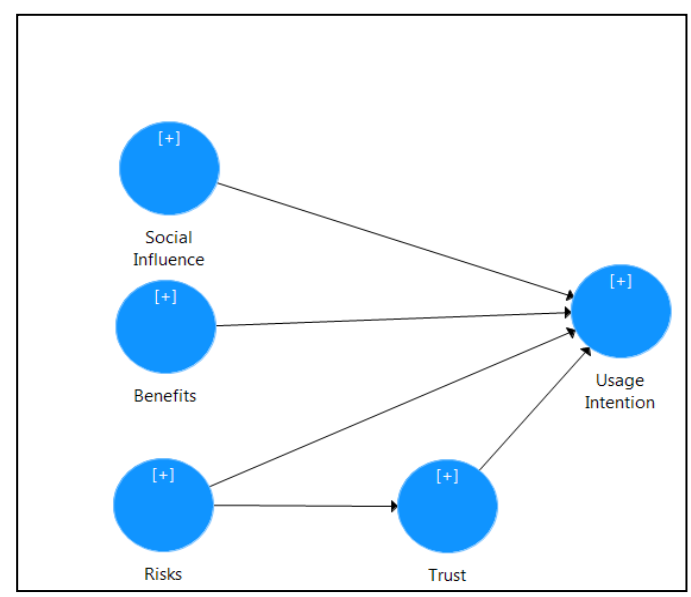

Figure 1. Research model.

The hypotheses development and the main constructs used in the model are discussed in depth in the following subsections.

\subsection{Perceived Trust}

Trust is considered crucial for technology adoption, especially those technologies designed for financial transactions [57-59]. In a highly competitive financial services industry, there is an emphasis on trust to build strong relationships with customers [40]. Trust is defined as "the willingness of a party to be vulnerable to the actions of another party based on the expectation that the other will perform a particular action important to the trustor, irrespective of the ability to monitor or control that other party" [60].

Trust in FinTech applications means that users have confidence in the ability, integrity and benevolence of these applications $[8,61,62]$. On the other hand, since the switching cost to traditional financial systems is high, trust is considered crucial for financial service providers [63-67].

Indeed, the outcome of trust in such uncertain and risky situations is reduced risk and therefore positive intentions toward using new technologies $[8,57,58,68]$. Therefore, the following hypothesis is proposed:

Hypothesis 1 (H1). Trust in FinTech applications has a positive effect on users' behavioral intention.

\subsection{Benefits}

Recently, innovations in ICT have provided customers with many new financial services [3,5]. FinTech applications may make mobile financial transactions convenient, cost effective and transparent [43]. FinTech provides customers with many benefits, mainly reduced time, effort and cost to accomplish financial transactions $[43,44]$. Perceived benefits are defined as "a users' perception of the potential that FinTech use will result in a positive outcome" [43]. Perceived benefits can reflect the utilities derived from using FinTech applications $[3,8,43]$. The degree to which customers believe the systems are useful and easy to use influences their intention to use these systems [43,45]. Accordingly, many research results indicate that perceived benefits can positively influence customers' intention to use FinTech applications such as mobile payment and Bitcoin [43,44,69]. Based on that, the following hypotheses are proposed:

Hypothesis 2 (H2). Perceived benefits have a positive and significant impact on users' FinTech behavioral intention. 


\subsection{Perceived Risk}

In the financial services context, innovations always come with high risk [43,55,70,71]. Perceived risk associated with FinTech usage is considered a fundamental barrier for technology adopters [43]. Perceived risk in FinTech is defined as "users' perception of the uncertainty and the possible negative consequences regarding the FinTech use." [43].

Perceived risks associated with FinTech applications can be classified into operational, financial, security and privacy concerns $[40,43,71]$.

These risks make customers more reluctant to use FinTech, thereby decreasing their intention to use these applications. Moreover, due to the intangibility of FinTech applications, the perceived risks of cyber threats and monetary loss inhibit users from using these services [5,8].

According to previous research findings, perceived risk has been found to be negatively related to the intention to use FinTech applications [8,43]. Furthermore, perceived risks and trust have a direct and reciprocal influence on customers' FinTech behavioral intention [40,55,71-73]. Hence, the following hypotheses are proposed:

Hypothesis 3 (H3). Perceived risks associated with FinTech applications have a negative effect on users' behavioral intention.

Hypothesis 4 (H4). Perceived risks associated with FinTech applications have a negative effect on customers' trust to use these applications.

\subsection{Social Influence}

Customers' decisions to use new technology, especially in the social media era, are influenced mainly by the opinions of other people surrounding them [74-76]. Family, friends and colleagues are all sources of positive recommendations about new technologies that may encourage customers to adopt them [66]. Users habitually use their mobile services in a social context where they are influenced by others' behavior [66,77].

Social influence, also known as subjective norms or images, is defined as "the extent to which an individual perceives that important others believe he or she should apply the new system" [54]. Social influence has a positive and significant impact on FinTech applications such as mobile payment and banking and intentions to use them [67,76,78-80], but this is subject to provisos, such as previous experience. Given the collectivistic culture of Jordanian society, the following hypotheses are proposed:

Hypothesis 5 (H5). Social influence has a positive effect on users' behavioral intention regarding FinTech applications.

\section{Methodology}

In order to achieve the aim of this study of examining the intention to use FinTech applications among Jordanian citizens during the COVID-19 pandemic, an online survey was developed based on an intensive literature review. The survey consisted of two sections: demographics and measurement items, using a five-point Likert scale ranging from (" 1 , strongly disagree" to " 5 , strongly agree"). The survey was designed in English language and then translated into Arabic language by an experienced translator. A second translator then back-translated the Arabic version into English to check the fidelity of the items in Arabic (no significant discrepancies were found). The structure of the survey and the relevant studies are shown in the Appendix A.

Before conducting the main survey, a pilot study was performed among 15 Jordanian academics in information systems and business fields to test the validity and reliability of the survey instruments. After that, over a period of one month (May 2020), and because of the lockdown restrictions, the survey was distributed in Jordan through different social network platforms. A total of 500 responses were 
collected, 49 of which were discarded as they were considered incomplete, or from unengaged respondents or outliers.

The collected data from this survey were analyzed using Microsoft Excel 2010, SPSS 20 and SmartPLS 3.2.4. The data were first coded and screened for possible outliers using Excel and SPSS and then the research hypotheses were tested using structural equation modeling (SEM) with SmartPLS. Demographic characteristics of the sample are presented in Table 1.

Table 1. Demographics.

\begin{tabular}{cccc}
\hline \multirow{3}{*}{ Gender } & & Frequency & Percentage \\
& Female & 220 & 48.8 \\
& Male & 231 & 51.2 \\
\hline \multirow{3}{*}{ Age } & $18-24$ & 136 & 30.1 \\
& $25-30$ & 61 & 13.5 \\
& $31-39$ & 143 & 31.7 \\
\multirow{2}{*}{ Bank Account } & $>=40$ & 111 & 24.7 \\
\hline \multirow{2}{*}{ Yes } & 366 & 81.2 \\
& No & 85 & 18.8 \\
\hline
\end{tabular}

Before conducting the final analysis, the common method variance (CMV) was tested using Harman's single factor test [81]. The results showed that three factors were extracted with an eigenvalue that was greater than 1 , and no single factor explained the majority of the variance, indicating that no serious common method bias was presented.

\section{Results}

The partial least square (PLS) approach of structural equation modeling (SEM) was employed to test the hypotheses of the conceptual model. The (PLS-SEM) method is considered suitable as the objective of the research is exploratory, and predictive, with less sample size and distribution restrictions or data collection challenges experienced during the COVID-19 lockdown [82-84]. The data analysis followed two phases; the first was evaluating the measurement model and the second was assessing the structural model, followed by post-hoc analysis, as explained below.

\subsection{Measurement Model}

The assessment of the measurement model included loadings, reliability, convergent validity and discriminant validity. The first step in the assessment was examining indicators loadings [84]. Loadings above 0.7 are recommended for acceptable item reliability. As shown in Table 2, all factors loadings have exceeded 0.7 .

The second step was assessing internal consistency reliability [84]. Composite reliability metric was used with a 0.7 threshold value. As shown in Table 2, composite reliability values of all constructs were more than 0.7 , which indicates a good internal consistency.

The third step was assessing convergent validity [84]. Average variance extracted (AVE) was used with a value for each construct that should exceed 0.5. As shown in Table 2, AVE values for all the constructs have exceeded 0.5.

The forth step was assessing discriminant validity. Different metrics were used to make sure that each construct was distinct from other constructs. Fornell and Larcker (1981) suggest that each construct's AVE value is greater than its correlation with other constructs $[84,85]$. As shown in Table 3 , all diagonal values were higher than other values for each column. Moreover, Henseler et al. (2015) proposed the heterotrait-monotrait ratio (HTMT) to also test constructs' discriminant validity [84]. Problems occur when HTMT values are high; for similar constructs the threshold value is (0.9), while for distinct constructs it is (0.85). As shown in Table 4, all HTMT values were below the threshold value. 
Table 2. Results of the measurement model analysis.

\begin{tabular}{|c|c|c|c|c|}
\hline Construct & Loadings & Cronbach's Alpha & Composite Reliability & Average Variance Extracted (AVE) \\
\hline Benefits & & 0.91 & 0.937 & 0.788 \\
\hline B1 & 0.856 & & & \\
\hline B2 & 0.89 & & & \\
\hline B3 & 0.931 & & & \\
\hline B4 & 0.872 & & & \\
\hline Risks & & 0.769 & 0.864 & 0.68 \\
\hline PR1 & 0.856 & & & \\
\hline PR2 & 0.88 & & & \\
\hline PR3 & 0.729 & & & \\
\hline Social Influence & & 0.868 & 0.919 & 0.791 \\
\hline SI1 & 0.89 & & & \\
\hline SI2 & 0.875 & & & \\
\hline SI3 & 0.903 & & & \\
\hline Trust & & 0.904 & 0.908 & 0.777 \\
\hline $\mathrm{T} 1$ & 0.88 & & & \\
\hline $\mathrm{T} 2$ & 0.873 & & & \\
\hline T3 & 0.855 & & & \\
\hline $\mathrm{T} 4$ & 0.917 & & & \\
\hline Usage Intention & & 0.866 & 0.918 & 0.789 \\
\hline UI1 & 0.907 & & & \\
\hline UI2 & 0.898 & & & \\
\hline UI3 & 0.859 & & & \\
\hline
\end{tabular}

Table 3. Discriminant validity average variance extracted (AVE) values.

\begin{tabular}{cccccc}
\hline & Benefits & Risks & Social Influence & Trust & Usage Intention \\
\hline Benefits & 0.888 & & & & \\
\hline Risks & -0.323 & 0.825 & & & \\
\hline Social Influence & 0.426 & -0.118 & 0.889 & & \\
\hline Trust & 0.692 & -0.378 & 0.509 & 0.882 & 0.888 \\
\hline Usage Intention & 0.798 & -0.303 & 0.466 & 0.686 & \\
\hline
\end{tabular}

Table 4. Discriminant validity heterotrait-monotrait (HTMT) values.

\begin{tabular}{cccccc}
\hline & Benefits & Risks & Social Influence & Trust & Usage Intention \\
\hline Benefits & & & & & \\
\hline Risks & 0.371 & & & \\
\hline Social Influence & 0.474 & 0.134 & & & \\
\hline Trust & 0.761 & 0.443 & 0.573 & 0.775 \\
\hline Usage Intention & 0.898 & 0.348 & 0.532 & \\
\hline
\end{tabular}

\subsection{Structural Model}

When the assessment of the measurement model is satisfactory, the next step is assessing the structural model by examining its explanatory power and the statistical significance of the path coefficients. Before assessing the structural model, multicollinearity among constructs must be examined. Collinearity issues occur with variance inflation (VIF) values above 5 [84]. As shown in Table 5, VIF values for all constructs' items were less than 5. In order to assess the model's explanatory 
power, the coefficient of determination (R2) is measured for all endogenous constructs. As shown in Table 6, R2 value for usage intention construct indicates that the model can be considered with a moderate explanatory power.

Table 5. Variance inflation (VIF) values.

\begin{tabular}{cc}
\hline & VIF \\
\hline Benefits & \\
\hline B1 & 2.278 \\
\hline B2 & 3.004 \\
\hline B3 & 4.245 \\
\hline B4 & 2.703 \\
\hline Perceived Risks & \\
\hline PR1 & 1.645 \\
\hline PR2 & 1.725 \\
\hline PR3 & 1.437 \\
\hline Social Influence & \\
\hline SI1 & 2.312 \\
\hline SI2 & 2.238 \\
\hline SI3 & 2.277 \\
\hline Trust & \\
\hline T1 & 2.533 \\
\hline T2 & 2.548 \\
\hline T3 & 2.445 \\
\hline T4 & 3.429 \\
\hline Usage Intention & \\
\hline UI1 & 2.526 \\
\hline UI2 & 2.422 \\
\hline UI3 & 1.979 \\
\hline & \\
\hline & \\
\hline & \\
\hline & \\
\hline & \\
\hline & \\
\hline & \\
\hline & \\
\hline & \\
\hline & \\
\hline & \\
\hline & \\
\hline & \\
\hline & \\
\hline & \\
\hline & \\
\hline & \\
\hline
\end{tabular}

Table 6. Coefficient of determination (R2) values.

\begin{tabular}{ccc}
\hline & R Square & R Square Adjusted \\
\hline Trust & 0.143 & 0.141 \\
\hline UI & 0.679 & 0.676 \\
\hline
\end{tabular}

In order to test the statistical significance of the path coefficients, a complete bootstrapping procedure was employed with 5000 samples. The results of the structural model analysis are shown in Figure 2.

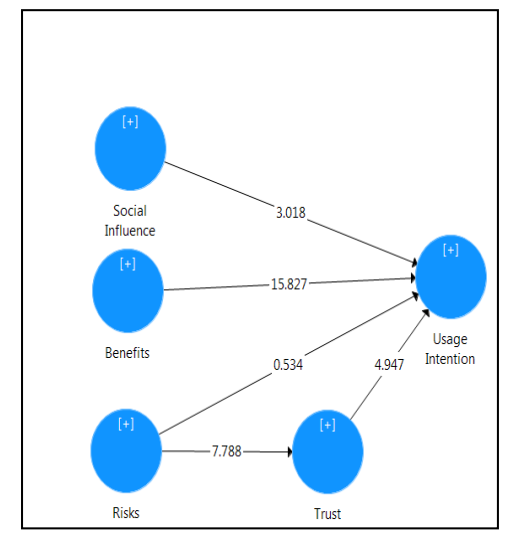

Figure 2. Results of hypotheses tests. 
As shown in Table 7, all hypotheses, except H3, are supported. Perceived benefits has a positive and significant relationship to usage intention $(\beta=0.605 ; p<0.05)$, thus $\mathrm{H} 2$ is supported. On the other hand, perceived risk has a non-significant relationship to usage intention; accordingly, $\mathrm{H} 3$ is not supported. Meanwhile, perceived risk has a negative and significant relationship to trust $(\beta=-0.378$; $p<0.05)$, therefore, $\mathrm{H} 4$ is supported. Furthermore, social influence has a positive significant relationship to usage intention ( $\beta=0.099 ; p<0.05)$, thus, $\mathrm{H} 5$ is supported. Finally, trust has a positive and significant relationship to usage intention $(\beta=0.21 ; p<0.05)$, thus, $\mathrm{H} 1$ is supported.

Table 7. Path coefficient.

\begin{tabular}{cccccc}
\hline & Original Sample (O) & Sample Mean (M) & $\begin{array}{c}\text { Standard Deviation } \\
\text { (STDEV) }\end{array}$ & $\begin{array}{c}\text { T Statistics } \\
(\mid \mathbf{O} / \text { STDEV|) }\end{array}$ & $p$ Values \\
\hline $\begin{array}{c}\text { Benefits -> Usage } \\
\text { Intention }\end{array}$ & 0.605 & 0.605 & 0.038 & 15.827 & 0 \\
\hline Risks -> Trust & -0.378 & -0.382 & 0.049 & 7.788 & 0 \\
\hline $\begin{array}{c}\text { Risks -> Usage } \\
\text { Intention }\end{array}$ & -0.016 & -0.016 & 0.03 & 0.534 & 0.594 \\
\hline $\begin{array}{c}\text { Social Influence -> } \\
\text { Usage Intention }\end{array}$ & 0.21 & 0.21 & 0.042 & 4.947 & 0 \\
\hline $\begin{array}{c}\text { Trust -> Usage } \\
\text { Intention }\end{array}$ & 0.605 & 0.605 & 0.038 & 15.827 & 0 \\
\hline
\end{tabular}

\subsection{Post-Hoc Analysis}

According to the results in Table 8, the indirect effect between perceived risk and usage intention is statistically significant. As declared above, perceived risk does not have a significant direct effect on usage intention. However, perceived risk has a significant effect on trust, which in turn has a significant effect on usage intention. This indicates that trust fully mediates the relationship between perceived risk and usage intention [84].

Table 8. Indirect effect.

\begin{tabular}{|c|c|c|c|c|c|}
\hline & Original Sample (O) & Sample Mean (M) & $\begin{array}{c}\text { Standard Deviation } \\
\text { (STDEV) }\end{array}$ & $\begin{array}{c}\text { T Statistics } \\
\text { (|O/STDEV|) }\end{array}$ & $p$ Values \\
\hline $\begin{array}{l}\text { Risks -> Trust -> } \\
\text { Usage Intention }\end{array}$ & -0.08 & -0.081 & 0.02 & 3.937 & 0 \\
\hline
\end{tabular}

\section{Discussion}

Compared to the wide spread use of FinTech applications in developed countries, this usage is still in its infancy stages in developing countries [3,4,21]. However, it has been noticed that during COVID-19 lockdown in Jordan, more than 100,000 new electronic wallets were issued [11]. During the lockdown, the Jordanian government and the Central Bank of Jordan have supported their customers to use FinTech applications in order to accomplish their financial transactions [11,15].

The purpose of this study was to empirically measure individuals' behavioral intention toward using FinTech applications during the COVID-19 crisis. To achieve this goal, social constructs from the extended valence framework, such as trust and risk, were integrated into the original UTAUT model. The study results promise to explain the role of using FinTech applications in building resilience during crisis. The study findings also show important theoretical and practical implications for FinTech application usage during crises.

The study findings revealed that perceived benefits had the most significant direct impact on individuals' intention to use FinTech applications during crises. These results are consistent with the results from previous studies $[43,57,59,66]$. Surprisingly, individuals' perceptions of technology risks did not affect their intention to use FinTech applications. These results are in line with other research results from developing countries $[46,71,79]$. However, these findings are in contrast to other studies which found that perceived technology risks significantly affect users' 
intentions $[8,43,57-59,75]$. These findings can be explained as suggesting the effect of individuals' fears during the COVID-19 pandemic was hiding their fears of technology risks, especially in developing countries. Moreover, these findings also indicate that individuals' intentions regarding using FinTech applications are more influenced by their benefits rather than their perceived risks. The high expected value from using FinTech applications should encourage financial institutions to provide new strategies, models and financial services in the field of FinTech applications. However, FinTech service providers should not neglect the risk associated with their services. They should increase security awareness and focus on building risk-free FinTech services as customers will later have these concerns after this crisis is finished. Moreover, as supported by previous research $[9,70,77]$, the collectivistic culture among Jordanians explains the significant impact of social norms on their intention to use FinTech applications.

In the review of our results, trust significantly affects individuals' intention to use FinTech applications, affirming previous literature positing trust is considered as one of the main factors affecting intention to use $[48,51,59,63,71,86]$. Trust is also found fully mediating the relationship between perceived risks and intention to use, supporting previous research results $[65,67]$. This implies that, since perceived risks had a significant negative effect on trust, increase in trust in FinTech applications will reduce perceived risk from using these technologies. These findings state that customer trust is considered an important practical implication for FinTech service providers, which should seriously consider trust-building strategies in order to promote using their products.

In light of the COVID-19 crisis, the infection could be transmitted through many mediums, one of them is cash. Access to cash during the COVID-19 crisis was a major concern during lockdowns, especially in developing countries. Moreover, governments struggled to financially help vulnerable citizens and businesses to access cash during this crisis. To ensure inclusivity, governments should support the use of such applications by establishing FinTech business incubators, marketing, reducing taxes and easing their regulations. Finally, governments and FinTech service providers should realize the role of these products in building community resilience during crises. These findings are all supported by previous research recommendations about the role of ICT and its applications, including FinTech, in building resilience during crises $[4,30,33,87,88]$.

\section{Conclusions, Limitations and Directions for Future Research}

This research employed a modified version of the UTAUT theory to examine the intention to use FinTech applications. The study outcomes highlight the role of consumer trust in FinTech applications to build resilience during crises. The survey obtained 451 valid forms from users and SEM was used to examine the research model and its corresponding hypotheses. The key factors necessary to drive customers' intention to use FinTech applications were identified and empirically examined.

The research results indicate that a customer's intention to use FinTech applications is affected by his or her perception of benefits, social impact and trust. However, during the COVID-19 pandemic perceptions of risks did not affect customers' intention to use FinTech applications but it affected their trust in the service. Moreover, the results of post-hoc analysis indicated that customers' trust toward FinTech significantly mediates the relationship between perceived risks and intention to use FinTech applications. Accordingly, consumers will be more likely to make FinTech transactions when perceived benefits, social value and trust are high and at the same time when risks perceptions are low.

This research is considered one of the first studies in the developing countries to empirically test the role of FinTech application during crises. Although this research provides several contributions, it still has many limitations, most notably that the survey data were collected online from Jordanian customers with a small sample size relative to the mobile usage penetration. This limits the research generalizability, in terms of randomization and different cultures. Moreover, this research also did not examine the moderation effects of users' demographic characteristics, such as age, gender and experience. Further research may also focus on other environmental factors, mainly the role of government regulations in FinTech adoption. These aspects should be investigated by subsequent 
studies, building on the findings of this exploratory research to understand FinTech adoption and actual usage in Jordan and other contexts.

Funding: This research received no external funding.

Conflicts of Interest: The authors declare no conflict of interest.

\section{Appendix A}

\begin{tabular}{|c|c|c|}
\hline & Factors & Reference \\
\hline \multicolumn{3}{|c|}{ Social Influence (SI) } \\
\hline SI1 & $\begin{array}{l}\text { People who are important to me think that I } \\
\text { should use FinTech. }\end{array}$ & \multirow{3}{*}{$\begin{array}{l}\text { Venkatesh V. Thong J.Y.L. Xu X. Consumer } \\
\text { Acceptance and Use of Information Technology. } \\
\text { MIS Q [Internet]. } 2012 .\end{array}$} \\
\hline SI2 & $\begin{array}{l}\text { People who influence my behaviour think } \\
\text { that I should use FinTech. }\end{array}$ & \\
\hline SI3 & $\begin{array}{l}\text { People whose opinions I value prefer that I } \\
\text { use FinTech. }\end{array}$ & \\
\hline \multicolumn{3}{|c|}{ Perceived Risk (PR) } \\
\hline PR1 & $\begin{array}{l}\text { Using FinTech is associated with a high } \\
\text { level of risk. }\end{array}$ & \multirow{3}{*}{$\begin{array}{l}\text { Kim D.J. Ferrin D.L. Rao H.R. A trust-based } \\
\text { consumer decision-making model in electronic } \\
\text { commerce: The role of trust, perceived risk, } \\
\text { and their antecedents. Decision Support Syst. } \\
2008 .\end{array}$} \\
\hline PR2 & $\begin{array}{l}\text { There is a high level of uncertainty } \\
\text { using FinTech. }\end{array}$ & \\
\hline PR3 & $\begin{array}{l}\text { Overall, I think that there is little benefit to } \\
\text { using FinTech compared to traditional } \\
\text { financial services. }\end{array}$ & \\
\hline \multicolumn{3}{|c|}{ Trust (T) } \\
\hline $\mathrm{T} 1$ & I trust RMP systems to be reliable. & \multirow{4}{*}{$\begin{array}{l}\text { Shaw N. The mediating influence of trust in the } \\
\text { adoption of the mobile wallet. J Retail Consumer } \\
\text { Service [Internet]. } 2014 \text {. }\end{array}$} \\
\hline $\mathrm{T} 2$ & I trust RMP systems to be secure. & \\
\hline $\mathrm{T} 3$ & I believe RMP systems are trustworthy. & \\
\hline $\mathrm{T} 4$ & I trust RMP systems. & \\
\hline \multicolumn{3}{|c|}{ Perceived Benefits (PB) } \\
\hline B1 & Using FinTech has many advantages. & \multirow{4}{*}{$\begin{array}{l}\text { Kim D.J., Ferrin D.L., Rao H.R. A trust-based } \\
\text { consumer decision-making model in electronic } \\
\text { commerce: The role of trust, perceived risk, } \\
\text { and their antecedents. Decision Support } \\
\text { Syst. } 2008 .\end{array}$} \\
\hline B2 & I can easily and quickly use FinTech. & \\
\hline B3 & Using FinTech is useful for me. & \\
\hline B4 & $\begin{array}{l}\text { Using FinTech yields a more superior } \\
\text { outcome quality than traditional financial } \\
\text { services. }\end{array}$ & \\
\hline \multicolumn{3}{|c|}{ Usage Intention (UI) } \\
\hline UI1 & I intend to adopt FinTech in the future. & \multirow{3}{*}{$\begin{array}{l}\text { Venkatesh V., Thong J.Y.L., Xu X. Consumer } \\
\text { Acceptance and Use of Information Technology. } \\
\text { MIS Q [Internet]. } 2012 .\end{array}$} \\
\hline UI2 & $\begin{array}{l}\text { I predict that I will frequently use FinTech } \\
\text { in the future. }\end{array}$ & \\
\hline UI3 & $\begin{array}{l}\text { I will strongly recommend others to } \\
\text { use FinTech. }\end{array}$ & \\
\hline
\end{tabular}




\section{References}

1. Karusala, N.; Holeman, I.; Anderson, R. Engaging identity, assets, and constraints in designing for resilience. Proc. ACM Hum. Comput. Interact. 2019, 3, 1-23. [CrossRef]

2. Adaba, G.B.; Ayoung, D.A.; Abbott, P. Exploring the contribution of mobile money to well-being from a capability perspective. Electron. J. Inf. Syst. Dev. Ctries. 2019, 85, 1-11. [CrossRef]

3. Puschmann, T. Fintech. Bus. Inf. Syst. Eng. 2017, 59, 69-76. [CrossRef]

4. Bharadwaj, P.; Jack, W.; Suri, T. Fintech and Household Resilience to Shocks: Evidence from Digital Loans in Kenya; National Bureau of Economic Research: Cambridge, MA, USA, 2019.

5. Gomber, P.; Kauffman, R.J.; Parker, C.; Weber, B.W. On the Fintech revolution: Interpreting the forces of innovation, disruption, and transformation in financial services. J. Manag. Inf. Syst. 2018, 35, $220-265$. [CrossRef]

6. Chen, M.A.; Wu, Q.; Yang, B. How valuable is Finttech innovation? Rev. Financ. Stud. 2019, 32, $2062-2106$. [CrossRef]

7. KPMG. The Pulse of Fintech 2019-Biannual Global Analysis of Investment in Fintech; KPMG: Zurich, Switzerland, 2019; p. 80.

8. Stewart, H.; Jürjens, J. Data security and consumer trust in FinTech innovation in Germany. Inf. Comput. Secur. 2018, 26, 109-128. [CrossRef]

9. Narteh, B.; Mahmoud, M.A.; Amoh, S. Customer behavioural intentions towards mobile money services adoption in Ghana. Serv. Ind. J. 2017, 37, 426-447. [CrossRef]

10. Kiconco, R.I.; Rooks, G.; Solano, G.; Matzat, U. A skills perspective on the adoption and use of mobile money services in Uganda. Inf. Dev. 2019, 35, 724-738. [CrossRef]

11. CBJ. Corona Crisis. 2020. Available online: http://www.cbj.gov.jo/Pages/viewpage.aspx?pageID=409 (accessed on 10 August 2020).

12. Carlsson-Szlezak, P.; Reeves, M.; Swartz, P. Understanding the economic shock of coronavirus. Harv. Bus. Rev. 2020. Available online: https://hbr.org/2020/03/understanding-the-economic-shock-of-coronavirus (accessed on 10 August 2020).

13. WTO. Trade Set to Plunge as COVID-19 Pandemic Upends Global Economy. 2020. Available online: https://www.wto.org/english/news_e/pres20_e/pr855_e.htm (accessed on 10 August 2020).

14. Staff, W. The Jordan Times. Kingdom is 'on Right Track' in Dealing with COVID-19. The Jordan Times, 29 March 2020. Available online: https://www.zawya.com/mena/en/life/story/Kingdom_is_on_right_track_in_dealing with_COVID19_majority_of_Jordanians_believe__poll-SNG_171284914/(accessed on 10 August 2020).

15. Singh, M.; The Washington Institute. Jordan after COVID-19: From Crisis Adjustment to Crisis Management. 2020. Available online: https://www.washingtoninstitute.org/fikraforum/view/Jordan-response-COVID19pandemic-Middle-East (accessed on 10 August 2020).

16. Al-Saeed, W.B.A.; El Khalil, Z. Jordan: COVID-19 Pandemic Weighs Heavily on the Economy, as it Does on the Region. Available online: https:/www.worldbank.org/en/news/press-release/2020/07/14/jordan-covid19-pandemic-weighs-heavily-on-the-economy-as-it-does-on-the-region (accessed on 9 October 2020).

17. Sahand, B.; Liasi, G.; Shahbazian, A.; Bina, M.T. COVID-19 Pandemic. Challenges and Opportunities: The Case of Jordan. Available online: https://www.euromesco.net/publication/covid-19-pandemicchallenges-and-opportunities-the-case-of-jordan/ (accessed on 6 June 2020).

18. UNDP. Impact of COVID 19 on Most Vulnerable Households. 2020. Available online: https://www.jo.undp.org/ content/jordan/en/home/library/covid-19-impact-on-most-vulnerable-households-in-jordan.html (accessed on 10 August 2020).

19. Digital Finance Country Report. Available online: http://tanmeyahjo.com/Portals/0/Digital\%20Finance\% 20COUNTRY\%20REPORT\%20(USAID\%20LENS).pdf?ver=2019-04-02-133749-100 (accessed on 10 August 2020).

20. Arner, R.P.; Barberis, D.W.; Buckley, J.N. The Evolution of Fintech: A New Post-Crisis Paradigm? SSRN Electron. J. 2015, 1-45. [CrossRef]

21. Goldstein, I.; Jiang, W.; Karolyi, G.A. To FinTech and beyond. Rev. Financ. Stud. 2019, 32, $1647-1661$. [CrossRef]

22. Dhar, V.; Stein, R.M. Economic and business dimensions: FinTech platforms and strategy. Commun. ACM 2017, 60, 32-35. [CrossRef] 
23. Gozman, D.; Liebenau, J.; Mangan, J. The innovation mechanisms of Fintech start-ups: Insights from SWIFT's innotribe competition. J. Manag. Inf. Syst. 2018, 35, 145-179. [CrossRef]

24. Karagiannaki, A.; Vergados, G.; Fouskas, K. The Impact of Digital Transformation in the Financial Services Industry: Insights from an Open Innovation Initiative in Fintech in Greece. In Proceedings of the Mediterranean Conference on Information, Genova Italy, 4-5 September 2017; pp. 1-12. Available online: http://aisel.aisnet.org/mcis2017/2/ (accessed on 10 August 2020).

25. DesJardine, M.; Bansal, P.; Yang, Y. Bouncing back: Building resilience through social and environmental practices in the context of the 2008 global financial crisis. J. Manag. 2019, 45, 1434-1460. [CrossRef]

26. Tabetando, R.; Matsumoto, T. Mobile money, risk sharing, and educational investment: Panel evidence from rural Uganda. Rev. Dev. Econ. 2020, 24, 84-105. [CrossRef]

27. Kingiri, A.N.; Fu, X. Understanding the diffusion and adoption of digital finance innovation in emerging economies: M-Pesa money mobile transfer service in Kenya. Innov. Dev. 2020, 10, 67-87. [CrossRef]

28. Varga, D. Fintech, the New Era. Bp. Manag. Rev. 2017, 22-33. [CrossRef]

29. Goo, J.J.; Heo, J.Y. The impact of the regulatory sandbox on the fintech industry, with a discussion on the relation between regulatory sandboxes and open innovation. J. Open Innov. Technol. Mark. Complex. 2020, 6, 43. [CrossRef]

30. Heeks, R.; Ospina, A.V. Conceptualising the link between information systems and resilience: A developing country field study. Inf. Syst. J. 2019, 29, 70-96. [CrossRef]

31. Berggren, P.; van Laere, J.; Lundberg, M.; Johansson, B.J.E. Community resilience towards disruptions in the payment system. In Proceedings of the International ISCRAM Conference 2019, Iscram, Spain, 19-22 May 2019; pp. 1070-1076.

32. Arevian, A.C.; O’Hora, J.; Jones, F.; Mango, J.; Jones, L.; Willians, P.; Booker-Vaughns, J.; Jones, A.; Pulido, E.; Banner-Jackson, D.; et al. Participatory technology development to enhance community resilience. Ethn. Dis. 2018, 28, 493-502. [CrossRef]

33. Pal, A.; De', R.; Herath, T. The role of mobile payment technology in sustainable and human-centric development: Evidence from the post-demonetization period in India. Inf. Syst. Front. 2020, 22, 607-631. [CrossRef]

34. Liu, Y.; Wang, M.; Huang, D.; Huang, Q.; Yang, H.; Li, Z. The impact of mobility, risk, and cost on the users' intention to adopt mobile payments. Inf. Syst. E-Bus. Manag. 2019, 17, 319-342. [CrossRef]

35. Senyo, P.K.; Osabutey, E.L.C. Unearthing antecedents to financial inclusion through FinTech innovations. Technovation 2020, 98, 102155. [CrossRef]

36. Hussain, A.B.; Endut, N.; Das, S.; Chowdhury, M.T.A.; Haque, N.; Sultana, S.; Ahmed, K.J. Does financial inclusion increase financial resilience? Evidence from Bangladesh. Dev. Pract. 2019, 29, 798-807. [CrossRef]

37. Kim, M.; Zoo, H.; Lee, H.; Kang, J. Mobile financial services, financial inclusion, and development: A systematic review of academic literature. Electron. J. Inf. Syst. Dev. Ctries. 2018, 84, 1-17. [CrossRef]

38. Chauhan, S. Acceptance of mobile money by poor citizens of India: Integrating trust into the technology acceptance model. Info 2015, 17, 58-68. [CrossRef]

39. Oliveira, T.; Thomas, M.; Baptista, G.; Campos, F. Mobile payment: Understanding the determinants of customer adoption and intention to recommend the technology. Comput. Hum. Behav. 2016, 61, 404-414. [CrossRef]

40. Slade, E.L.; Dwivedi, Y.K.; Piercy, N.C.; Williams, M.D. Modeling consumers' adoption intentions of remote mobile payments in the United Kingdom: Extending UTAUT with innovativeness, risk, and trust. Psychol. Mark. 2015, 32, 860-873. [CrossRef]

41. Liébana-Cabanillas, F.; Sánchez-Fernández, J.; Muñoz-Leiva, F. Antecedents of the adoption of the new mobile payment systems: The moderating effect of age. Comput. Hum. Behav. 2014, 35, 464-478. [CrossRef]

42. Abdul-Hamid, I.K.; Shaikh, A.A.; Boateng, H.; Hinson, R.E. Customers' perceived risk and trust in using mobile money services-an empirical study of Ghana. Int. J. E-Bus. Res. 2019, 15, 1-19. [CrossRef]

43. Ryu, H. What makes users willing or hesitant to use Fintech? The moderating effect of user type. Ind. Manag. Data Syst. 2018, 118, 541-569. [CrossRef]

44. Kim, Y.; Youngju, P.; Jeongil, C.; Jiyoung, Y. An Empirical Study on the Adoption of “Fintech" Service: Focused on Mobile Payment Services. Ibusiness 2015, 136-140. [CrossRef] 
45. The Adoption of Mobile Payment Services for “Fintech". Available online: https://www.semanticscholar.org/ paper/The-Adoption-of-Mobile-Payment-Services-for-Kim-Park/2c968789b918883f6f189943f325b44aa69c9b9c (accessed on 13 November 2020).

46. Hu, Z.; Ding, S.; Li, S.; Chen, L.; Yang, S. Adoption intention of fintech services for bank users: An empirical examination with an extended technology acceptance model. Symmetry 2019, 11, 340. [CrossRef]

47. Chandra, S.; Srivastava, S.C.; Theng, Y.-L. Evaluating the role of trust in consumer adoption of mobile payment systems: An empirical analysis. Commun. Assoc. Inf. Syst. 2010, 27, 29. [CrossRef]

48. Xin, H.; Techatassanasoontorn, A.A.; Tan, F.B. Antecedents of consumer trust in mobile payment adoption. J. Comput. Inf. Syst. 2015, 55, 1-10. [CrossRef]

49. Shaikh, I.M.; Qureshi, M.A.; Noordin, K.; Shaikh, J.M.; Khan, A.; Shahbaz, M.S. Acceptance of Islamic financial technology (FinTech) banking services by Malaysian users: An extension of technology acceptance model. Foresight 2020, 22, 367-383. [CrossRef]

50. Arias-Oliva, M.; Pelegrín-Borondo, J.; Matías-Clavero, G. Variables influencing cryptocurrency use: A technology acceptance model in Spain. Front. Psychol. 2019, 10, 1-13. [CrossRef]

51. Patil, P.; Rana, N.; Dwivedi, Y.; Abu-Hamour, H. The Role of Trust and Risk in Mobile Payments Adoption: A Meta-Analytic Review. 2018, pp. 6-26. Available online: https://aisel.aisnet.org/pacis2018/129 (accessed on 10 August 2020).

52. Duane, A.; O'Reilly, P.; Andreev, P. Realising M-payments: Modelling consumers' willingness to M-pay using smart phones. Behav. Inf. Technol. 2014, 33, 318-334. [CrossRef]

53. Abdullah, E.M.E.; Rahman, A.A.; Rahim, R.A. Adoption of financial technology (Fintech) in mutual fund/unit trust investment among Malaysians: Unified theory of acceptance and use of technology (UTAUT). Int. J. Eng. Technol. 2018, 7, 110-118. [CrossRef]

54. Venkatesh, V.; Thong, J.Y.L.; Xu, X. Consumer acceptance and use of information technology. MIS Q. 2012, 36, 157-178. Available online: http://papers.ssrn.com/sol3/papers.cfm?abstract_id=2002388 (accessed on 10 August 2020). [CrossRef]

55. Kim, D.J.; Ferrin, D.L.; Rao, H.R. A trust-based consumer decision-making model in electronic commerce: The role of trust, perceived risk, and their antecedents. Decis. Support Syst. 2008, 44, 544-564. [CrossRef]

56. Pal, A.; De', R.; Herath, T.; Rao, H.R. A review of contextual factors affecting mobile payment adoption and use. J. Bank. Financ. Technol. 2019, 3, 43-57. [CrossRef]

57. Liébana-Cabanillas, F.; Muñoz-Leiva, F.; Sánchez-Fernández, J. A global approach to the analysis of user behavior in mobile payment systems in the new electronic environment. Serv. Bus. 2018, 12, 25-64. [CrossRef]

58. Shao, Z.; Zhang, L. Trust Building in the Mobile Payment Platform: The Moderating Effect of Gender. 2018. Available online: https://aisel.aisnet.org/pacis2018/5 (accessed on 10 August 2020).

59. Cao, X.; Yu, L.; Liu, Z.; Gong, M.; Adeel, L. Understanding mobile payment users' continuance intention: A trust transfer perspective. Internet Res. 2018, 28, 456-476. [CrossRef]

60. Davis, J.H. An integrative model of organizational trust. Acad. Manag. Rev. 2020, 20, 709-734.

61. Liao, C.; Liu, C.C.; Chen, K. Examining the impact of privacy, trust and risk perceptions beyond monetary transactions: An integrated model. Electron. Commer. Res. Appl. 2011, 10, 702-715. [CrossRef]

62. Lu, Y.; Yang, S.; Chau, P.Y.K.; Cao, Y. Dynamics between the trust transfer process and intention to use mobile payment services: A cross-environment perspective. Inf. Manag. 2011, 48, 393-403. [CrossRef]

63. Yang, Q.; Pang, C.; Liu, L.; Yen, D.C.; Tarn, J.M. Exploring consumer perceived risk and trust for online payments: An empirical study in China's younger generation. Comput. Hum. Behav. 2015, 50, 9-24. [CrossRef]

64. Al-Okaily, M.; Rahman, M.S.A.; Ali, A. Factors affecting the acceptance of mobile payment systems in Jordan: The moderating role of trust. J. Inf. Syst. Technol. Manag. 2019, 4, 16-26. [CrossRef]

65. Hariguna, T.; Adiandari, A.M.; Ruangkanjanases, A. Assessing customer intention use of mobile money application and the antecedent of perceived value, economic trust and service trust. Int. J. Web Inf. Syst. 2020, 16, 331-345. [CrossRef]

66. Beldad, A.D.; Hegner, S.M. Expanding the technology acceptance model with the inclusion of trust, social influence, and health valuation to determine the predictors of German users' willingness to continue using a fitness app: A structural equation modeling approach. Int. J. Hum. Comput. Interact. 2018, 34, 882-893. [CrossRef]

67. Singh, N.; Sinha, N. How perceived trust mediates merchant's intention to use a mobile wallet technology. J. Retail. Consum. Serv. 2020, 52, 101894. [CrossRef] 
68. Chaouali, W.; Yahia, I.B.; Souiden, N. The interplay of counter-conformity motivation, social influence, and trust in customers' intention to adopt Internet banking services: The case of an emerging country. J. Retail. Consum. Serv. 2016, 28, 209-218. [CrossRef]

69. Choi, H.; Jung, Y.; Choi, Y.R. Understanding of the fintech phenomenon in the beholder's eyes in South Korea. Asia Pac. J. Inf. Syst. 2019, 29, 117-143. [CrossRef]

70. Kesharwani, A.; Bisht, S.S. The impact of trust and perceived risk on internet banking adoption in India: An extension of technology acceptance model. Int. J. Bank Mark. 2012, 30, 303-322. [CrossRef]

71. Rouibah, K.; Lowry, P.B.; Hwang, Y. The effects of perceived enjoyment and perceived risks on trust formation and intentions to use online payment systems: New perspectives from an Arab country. Electron. Commer. Res. Appl. 2016, 19, 33-43. [CrossRef]

72. Kim, G.; Koo, H. The causal relationship between risk and trust in the online marketplace: A bidirectional perspective. Comput. Hum. Behav. 2016, 55, 1020-1029. [CrossRef]

73. Chin, A.G.; Harris, M.A.; Brookshire, R. A bidirectional perspective of trust and risk in determining factors that influence mobile app installation. Int. J. Inf. Manag. 2018, 39, 49-59. [CrossRef]

74. Ameen, N.; Hussain, M.; Sims, J.; Choudrie, J.; Willis, R. Are there peas in a pod when considering mobile phone and mobile applications use: A quantitative study. J. Retail. Consum. Serv. 2020, 55, 102067. [CrossRef]

75. Grover, P.; Kar, A.K. User engagement for mobile payment service providers-Introducing the social media engagement model. J. Retail. Consum. Serv. 2018, 53, 101718. [CrossRef]

76. Abrahão, R.D.S.; Moriguchi, S.N.; Andrade, D.F. Intention of adoption of mobile payment: An analysis in the light of the unified theory of acceptance and use of technology (UTAUT). RAI Rev. Adm. Inovação 2016, 13, 221-230. [CrossRef]

77. Koenig-Lewis, N.; Marquet, M.; Palmer, A.; Zhao, A.L. Enjoyment and social influence: Predicting mobile payment adoption. Serv. Ind. J. 2015, 35, 537-554. [CrossRef]

78. Alalwan, A.A.; Dwivedi, Y.K.; Rana, N.P.; Algharabat, R. Examining factors influencing Jordanian customers' intentions and adoption of internet banking: Extending UTAUT2 with risk. J. Retail. Consum. Serv. 2018, 40, 125-138. [CrossRef]

79. Jenkins, P.; Ophoff, J. Factors influencing the intention to adopt NFC mobile payments-A South African perspective. In Proceedings of the CONF-IRM 2016 Proceeding, Cape Town, South Africa, 18-20 May 2016.

80. Teo, A.C.; Tan, G.W.H.; Ooi, K.B.; Lin, B. Why consumers adopt mobile payment? A partial least squares structural equation modelling (PLS-SEM) approach. Int. J. Mob. Commun. 2015, 13, 478-497. [CrossRef]

81. Weber, E. Harman, Harry H.: Modern factor analysis. 2. durchges. Aufl. The Univ. of Chicago Press: Chicago und London, 1967. XX, 474 S., Tafelanhang, Preis \$12.50. Biom. J. 1970, 12, 67-68. [CrossRef]

82. Hair, J.F., Jr.; Sarstedt, M.; Hopkins, L.; Kuppelwieser, V.G. Partial least squares structural equation modeling (PLS-SEM). Sage Publ. 2014. [CrossRef]

83. Benitez, J.; Henseler, J.; Castillo, A.; Schuberth, F. How to perform and report an impactful analysis using partial least squares: Guidelines for confirmatory and explanatory IS research. Inf. Manag. 2020, 57, 103168. [CrossRef]

84. Hair, J.F.; Risher, J.J.; Sarstedt, M.; Ringle, C.M. Article information: When to use and how to report the results of PLS-SEM. Eur. Bus. Rev. 2018, 31, 2-24. [CrossRef]

85. Fornell, C.; Larcker, D.F. Evaluating structural equation models with unobservable variables and measurement error. J. Mark. Res. 1981, 18, 39-50. [CrossRef]

86. Malaquias, R.F.; Hwang, Y. An empirical study on trust in mobile banking: A developing country perspective. Comput. Hum. Behav. 2016, 54, 453-461. [CrossRef]

87. Afawubo, K.; Couchoro, M.K.; Agbaglah, M.; Gbandi, T. Mobile money adoption and households' vulnerability to shocks: Evidence from Togo. Appl. Econ. 2020, 52, 1141-1162. [CrossRef]

88. Lashitew, A.A.; van Tulder, R.; Liasse, Y. Mobile phones for financial inclusion: What explains the diffusion of mobile money innovations? Res. Policy 2019, 48, 1201-1215. [CrossRef]

Publisher's Note: MDPI stays neutral with regard to jurisdictional claims in published maps and institutional affiliations. 